DEMOGRAPHIC RESEARCH

VOLUME 41, ARTICLE 11, PAGES 293-330
PUBLISHED 25 JULY 2019

http://www.demographic-research.org/Volumes/Vol41/11/

DOI: 10.4054/DemRes.2019.41.11

Research Article

\title{
A framework for the prospective analysis of ethno-cultural super-diversity
}

\section{Alain Bélanger}

\section{Patrick Sabourin}

\section{Jennifer Van Hook}

\author{
Samuel Vézina
}

\section{Guillaume Marois}

This publication is part of the Special Collection on "Drivers and the potential impact of future migration in the European Union," organized by Guest Editors Alain Bélanger, Wolfgang Lutz, and Nicholas Gailey.

(C) 2019 Bélanger, Sabourin, Marois, Van Hook \& Vézina.

This open-access work is published under the terms of the Creative Commons Attribution 3.0 Germany (CC BY 3.0 DE), which permits use, reproduction, and distribution in any medium, provided the original author(s) and source are given credit.

See https://creativecommons.org/licenses/by/3.0/de/legalcode. 


\section{Contents}

1 Introduction $\quad 294$

$2 \quad$ The rise in super-diversity 294

3 Implications of super-diversity for population research 296

$4 \quad$ An analytical framework for the prospective analysis of super- 300 diversity

$5 \quad$ Microsimulation models for Canada, United States, and European 303

Union

6 Results 310

6.1 Example 1: Ethno-cultural diversity 311

6.2 Example 2: Immigration and linguistic composition 313

6.3 Example 3: The educational attainments of immigrants 314

6.4 Example 4: Regional variations 315

6.5 Example 5: A cohort perspective to economic dependency ratio $\quad 317$

$\begin{array}{lll}7 & \text { Discussion and conclusion } & 318\end{array}$

8 Acknowledgements $\quad 320$

$\begin{array}{ll}\text { References } & 321\end{array}$ 


\title{
A framework for the prospective analysis of ethno-cultural super-diversity
}

\author{
Alain Bélanger ${ }^{1}$ \\ Patrick Sabourin ${ }^{2}$ \\ Guillaume Marois $^{2}$ \\ Jennifer Van Hook ${ }^{3}$ \\ Samuel Vézina ${ }^{4}$
}

\begin{abstract}
BACKGROUND

Pressures to keep immigration rates at relatively high levels are likely to persist in most developed countries. At the same time, immigrant cohorts are becoming more and more diverse, leading host societies to become increasingly heterogeneous across multiple dimensions. For scholars who study demographic or socio-economic behaviours, the need to account for ethno-cultural "super-diversity" brings new challenges.
\end{abstract}

\section{OBJECTIVE}

The main objective of this paper is to present a framework for the prospective analysis of super-diversity in several high immigration countries.

\section{METHODS}

We developed microsimulation models that simultaneously project several population dimensions for Canada, the United States and countries of the European Union, with the aim of studying the consequences of alternate future population and migration trends.

\section{RESULTS}

The paper presents the projected progression of three indicators of diversity: percentage of foreign-born population, percentage of the population using a non-official language at home and percentage of non-Christians. It also examines the projected changes in the

${ }^{1}$ Institut National de la Recherche Scientifique (INRS), Canada and International Institute for Applied Systems Analysis (IIASA), Austria. Email: alain.belanger@ucs.inrs.ca.

${ }^{2}$ International Institute for Applied Systems Analysis (IIASA), Austria.

${ }^{3}$ Pennsylvania State University, USA.

${ }^{4}$ Institut National de la Recherche Scientifique (INRS), Canada. 
labour force by education levels and language. Using alternative scenarios, we also show that the proportion of highly educated in the US and EU28 labour force could increase by 11 and 15 percentage points respectively if future immigrants were selected as in Canada. Finally, the paper proposes a new longitudinal indicator that counts the number of years lived as active and inactive over the life course for foreign- and nativeborn cohorts.

\section{CONTRIBUTION}

The microsimulation models provide much more informative results than more traditional cohort-component models to study the future effects of ethno-cultural superdiversity on high immigration countries.

\section{Introduction}

In what Coleman (2006) terms the "Third Demographic Transition," immigration has led to rapid increases in cultural, ethnic, and religious diversity in many high-income, low-fertility countries. This rise in 'super-diversity' (Vertovec 2007) has challenged researchers and policy makers as they attempt to understand, anticipate the needs of, and develop policies and programs for multiple, highly diverse, subgroups. For demographers, the cohort-component projection model has long served as a crucial policy and planning tool, yet this macro-level approach is too blunt of an instrument for modeling. In this paper, we argue that a microsimulation approach is better suited for this task, and we demonstrate this approach using a microsimulation model we developed for Canada, the United States, and the 28 EU member states of the European Union.

\section{The rise in super-diversity}

Super-diversity has emerged in the broader context of a new demographic regime characterized by low fertility, high immigration, and population aging. Most developed countries are facing similar demographic changes: population aging, possible labour shortages (Mahroum 2001; Martin and Ruhs 2011; Ruhs and Anderson 2010), and reduced population growth, if not population decline (United Nations Population Division 2017). The Baby-Boom experienced by these countries after World War II was followed by a rapid fertility decline, which initiated population aging (Caldwell and Schindlmayr 2003; Coale and Watkins 1986; Gavrilov and Heuveline 2003). 
Boomers are now reaching retirement age and are being replaced by smaller cohorts of young workers, which may compromise a balance between labour force demand and supply in specific sectors of the labour market.

In response to these trends, most developed countries have increased their immigration to historically high levels. In fact, more people are living abroad than ever before. The United Nations estimates that there were 244 million migrants in 2013, up from 173 million in 2000, and more than two-thirds (71\%) of all international migrants live in developed regions (United Nations Population Division 2016). Accordingly, immigration rates have significantly increased in Canada, Australia, the United Kingdom, Austria, Italy, and elsewhere in Europe (Australian Department of Immigration and Citizenship 2012; Citizenship and Immigration Canada 2012; Coleman 2009; Jennissen, Van Der Gaag, and Van Wissen 2006; Zaiceva and Zimmermann 2008).

International net migration now accounts for about two-thirds of the total population growth of developed nations, outpacing natural increase (Population Reference Bureau 2012). Most observers believe that the current below-replacement fertility regime in Europe will hold true in the future (Frejka and Ross 2001; Lesthaeghe and Willems 1999; McDonald 2002). Furthermore, in a little more than a decade, the rate of natural increase will become negative in many developed countries, leaving immigration as the only positive driver of population growth (Lutz, Butz, and KC 2014). Moreover, in the context of population aging where a growing number of people are about to withdraw from the labour market, economic pressures to keep immigration rates at fairly high levels are likely to persist (Martel et al. 2007; Zimmermann et al. 2007).

At the same time, immigration to developed countries has become more culturally diverse (Cohen and Van Hear 2008; Coleman 2006; Massey et al. 1993), dramatically changing the nature of population diversity to such an extent that Vertovec (2007) was led to create the neologism super-diversity. The term refers to the fact that in many Western countries population diversity has increased to an unprecedented level due to both increased immigration levels and an increase in the number of source countries (Frey 2014). While past immigration to Canada, the United States, France, and Germany, as examples, was composed of a succession of cohorts of immigrants with similar demographic, socioeconomic, and geographical attributes, what characterizes the most recent immigration is the diversification of its sources and of the characteristics of its members. Thus, the diversity of the host population increases not only because of the increasing number or proportion of immigrants from diverse backgrounds but also because of their own diversification in terms of ethno-cultural or socioeconomic characteristics. Diversity thus has now multiple, overlapping dimensions involving sociocultural factors such as race, ethnicity, language, and 
religion, and a host of social and economic factors that are associated with these sociocultural factors. Recent censuses and surveys show increasing numbers and proportions of immigrants, of people belonging to visible minority (ethnic/racial) groups (Statistics Canada 2013), of speakers of nonofficial languages (Rampton, Harris, and Leung 1997; Statistics Canada 2007), and of people whose religion is not Christian (Goujon et al. 2007; Parsons 1994; Peach 2005; Statistics Canada 2003). These trends are expected to continue in the future (Winter and Teitelbaum 2013), raising questions about the long-term sustainability of Western countries' social security programs, healthcare, and retirement plans and inequalities (Anderson and Hussey 2000; Auerbach and Lee 2011; Lichter 2013; OECD 2000). Although Vertovec attaches some importance to the emergence of new high levels for these variables, he doesn't define super-diversity by a threshold, in terms of the percentage of the population of a country that has one or the other of these characteristics, but by the fact that the multiplicity of countries of origin that characterizes recent immigration results in multiple configurations that require a multi-dimensional perspective on diversity to better inform policies.

\section{Implications of super-diversity for population research}

It is becoming increasingly important for demographers to account for the multiple dimensions of ethno-cultural diversity in population projections. This is essential for research on the future consequences of immigration, and it would also serve to improve analyses of demographic and social trends that are not directly focused on immigration because of the way ethnic and cultural groups vary in their demographic and socioeconomic behaviours. On the demographic side, cultural-ethnic and national origin groups often vary with respect to the timing and occurrence of key demographic processes: fertility, marriage, mortality, and migration. For example, newcomers tend to show higher fertility (Abbasi-Shavazi and McDonald 2000; Andersson 2004; Bélanger and Gilbert 2003; Ng and Nault 1997; Trovato 1981) and lower mortality due to the healthy immigrant effect (Bourbeau 2002; Chen, Wilkins, and Ng 1996; Hummer, Benjamins, and Rogers 2004; Rees, Wohland, and Norman 2009; Singh and Miller 2004; Trovato 1985, 1993; Young 1987).

On the socioeconomic side, cultural-ethnic and national origin groups often differ in educational and employment outcomes. For example, newcomers in Canada show on average higher levels of educational attainment (Bonikowska, Green, and Riddell 2008; Geschwender and Guppy 1995; Picot 2008), as the immigration policy aims at selecting highly qualified candidates (Beach, Green, and Reitz 2003), regardless of the country of origin. In Europe, by contrast, few immigrants are selected according to their skills 
(Büchel and Frick 2005; Münz 2007; Ruhs 2008), and in the US low-skill immigrants make up a large share of legal and illegal immigration (Barrett 1998; Borjas 1987, 1989, 1994; Schultz 1998). Generally, when controlling for educational attainment, immigrants show lower labour force participation rates than natives (Aydemir and Skuterud 2005; Bloom, Grenier, and Gunderson 1994; Boudarbat and Boulet 2007, 2010; Boyd and Cao 2009; Ferrer and Riddell 2004; Kahn 2004; Meurs, Pailhé, and Simon 2006; Model and Lin 2002). However, the skill composition of immigrant flows affects the average labour force participation rates; immigrants tend to have higher participation rates in countries such as the US, or in Southern Europe, where they are generally less skilled (OECD 2010).

According to Preston, Heuveline, and Guillot (2000), the cohort-component method "is now nearly the only method used for population projections, representing a rare consensus for the social sciences." However, super-diversity is impossible to account for with standard cohort-component projection models. Although cohortcomponent projections are frequently produced separately for major demographic groups (such as by major racial or ethnic groups), they are inherently based on aggregated population estimates and rates and are not agile enough to handle multidimensional and dynamic forms of diversity.

First, cohort-component models, including its multi-state variants, have practical limits in the number of events, states, and groups that can be modeled. Typically, they provide information about projected population size, growth, age, and sex structure, and at the most one or two other dimensions, but they rarely provide information on socioeconomic characteristics. Yet, the prospective analysis of the consequences of super-diversity requires the simultaneous projection of a large number of individual characteristics or attributes, all of them having several categories. This extends beyond the capacity of the multistate model whose state space (matrix size) would have to include all possible combinations of attribute values.

Second, the cohort-component projection method tends to treat groups as mutually exclusive and separated fixed categories (e.g., immigrant status (Lanzieri 2011); race/ethnic groups (Colby and Ortman 2014; Rees et al. 2011, 2012); religion (Pew Research Center 2015); or language spoken (Termote, Payeur, and Thibault 2011)). Yet, under the super-diversity paradigm, group identities often involve multiple overlapping dimensions that do not fit neatly in mutually exclusive groups and often interact with each other. For example, not only are there differences between the labour force participation levels of immigrants and natives, differences which tend to diminish with the length of residence in the host country, but within the immigrant population itself the pace at which this gap is reduced also varies according to place of origin, membership of a particular ethnic group, linguistic proximity to the official language of the host country, and other characteristics. This type of interaction can easily be 
modelled within a microsimulation model but not easily within a multi-state model. Moreover, ethnic group identities may shift or fade over time, such that later generation group members no longer identify with the group. For example, Duncan and Trejo (2011) show substantial ethnic attrition among Hispanics that is strongly linked to interethnic marriage, which increases across generations and with higher levels of education. This process, which can be conceptualized as intra-generational and intergenerational ethnic mobility, can hardly be modelled with the cohort-component projection method.

Third, the microsimulation model can manage the heterogeneity problem much more effectively than the cohort-component. This is due again to the limitation regarding the number of states that can be practically implemented by the multi-state model. For example, most projections assume that all women have the same agespecific fertility rates, or all people experience the same age- and sex-specific mortality rates, when in fact, these processes are likely to depend on a number of socioeconomic and cultural factors. Additionally, the composition of groups may change over time. Indeed, it is widely thought that immigrants and their families undergo profound cultural and socioeconomic changes as a consequence of coming into contact with host societies, making it useful, if not necessary, to take into account the effect of duration. Although the pace (and even direction) of integration varies across groups, nearly all national origin groups in the United States or Canada speak English or French by the second generation (Bélanger, Lachapelle, and Sabourin 2011; Rumbaut, Massey, and Bean 2006), and among immigrant groups that arrived with low levels of education, educational attainment tends to increase substantially across generations (Park and Myers 2010). These limitations suggest that it would be useful to develop a projection model that goes beyond the cohort-component model.

We developed a microsimulation model to meet this need. The model is designed to provide prospective analyses of the socioeconomic and cultural consequences of population changes in high immigration countries. International in scope, we originally developed the model for Canada, but have since adapted it for other immigrationreceiving countries, including the United States and the 28 member countries of the European Union. The model could also be extended to other countries with similar demographic regimes, such as Australia. In developing the model, our main objective has been to study the possible consequences of alternate future immigration trends in order to inform policies about important issues such as the integration of new immigrants, social cohesion, labour force supply and composition in terms of education level and skills, or long-term sustainability of social security programs and retirement plans. To achieve this objective, the model encompasses as many socioeconomic and ethno-cultural indicators as are available for each projected population. 
It is important to mention that the proposed microsimulation projection model is not inherently opposed to the multi-state model. Both aim to model transitions between the different states that characterize a population (van Imhoff and Post 1998), the multistate model using population groups, and the microsimulation model using the individual. A multi-state model and a microsimulation model with the same characteristics (state space) will produce the same results, more or less the Monte-Carlo error associated with the stochastic process of microsimulation. The microsimulation model, however, becomes much more efficient when the state space increases, since its storage requirements grow linearly with the increase in projected population characteristics, while the other grows exponentially. In addition, it is very difficult, if not impossible, to take into account duration variables such as duration since immigration or age at arrival in a multi-state model, whereas this is relatively easy in microsimulation.

Our purpose for the remainder of the paper is to present the analytical framework behind this endeavour, describe the general structure of the microsimulation models, and share some of the results. We first describe the analytical framework of the research project and the general structure and logic of the microsimulation models in the next section. More detailed technical description of the modules that make up the model in terms of their events, their parameters, and their outputs can be found elsewhere $^{5}$ (Bélanger and Sabourin 2017; Bélanger et al. 2019, 2018; Lutz and Bélanger 2017; Marois, Sabourin, and Bélanger 2017). Next, we provide an overview of the similarities and differences of the concepts used in the different countries. Ideally, all markers of ethno-cultural diversity would be available for all countries of interest and have the same categories everywhere, but in reality, this is not the case. Finally, we present some results to illustrate how the microsimulation models can be used. We present results that assess the impact of immigration on the ethno-cultural (immigrant status, language, and religion) and socioeconomic (educational attainment and labour force participation) characteristics of each population. The results' section also examines the projected changes in the labour force in each country by education levels and language spoken, key characteristics for the analysis of economic integration.

\footnotetext{
${ }^{5}$ Additional methodological documentation is available at www.lsd.inrs.ca.
} 


\section{An analytical framework for the prospective analysis of super- diversity}

Unlike the cohort-component projection method, which uses aggregated population estimates as inputs and outputs, our microsimulation model operates at the individual level. It projects the occurrence and timing of demographic and socioeconomic events that shape future characteristics of individuals and their future offspring based on a series of interrelated multivariate prediction models. In this section, we describe the three analytic stages or steps we employed when developing the microsimulation models, as illustrated in Figure 1.

The first stage is devoted to the analysis of the effects of ethno-cultural characteristics on the demographic and socioeconomic behaviours of population groups. This analysis is necessary to estimate the parameters that will serve as inputs in the microsimulation model. It also provides the basis for a deeper comparative knowledge of demographic and socioeconomic behaviours of new immigrants in different Western countries. During this first phase, analytical efforts concentrate on deriving the net effects of ethno-cultural variables - such as race, religion, language use, and immigration status - on the components of population change and labour market outcomes. Control variables of interest include age, sex, and education level. The analyses aim at finding the impact of ethno-cultural variables on fertility, on the likelihood of participating in the labour force, or on the probability of achieving a given education level, to name but a few examples. Multivariate analyses are performed on available public microdata sets such as censuses or social surveys. Base risks by age and sex (and sometimes by other available variables, such as education) are usually derived from the most robust available data sources (often vital statistics). Ethnocultural differentials, which are sometimes derived from surveys with lower sample sizes, are added in the form of relative risks derived from regression parameters, controlling for variables included in the base risk. This method allows for maximum flexibility in the use of the various available data sources. Scenarios can then be built by modifying the base risks or by making alternative assumptions on the relative risks. 


\section{Figure 1: An analytical framework for the prospective analysis of super- diversity}

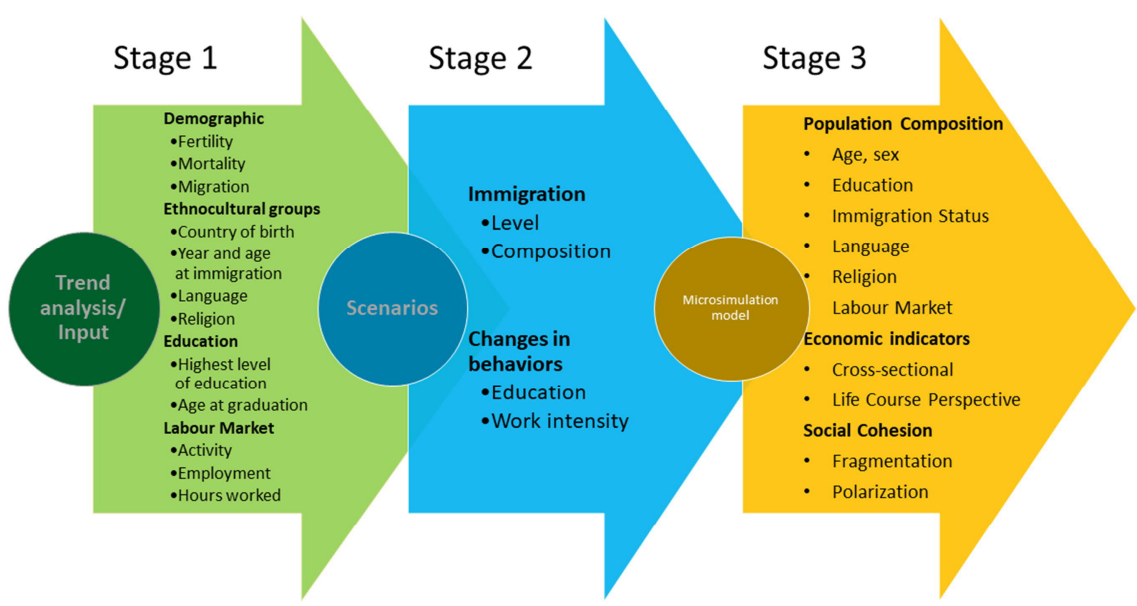

Our analysis of differentials in behaviours is rooted in the segmented assimilation thesis (Portes and Zhou 1993). As such, it is assumed that the process of acculturation, by which diverse ethnic groups come to share the culture and adopt the behaviours of the majority (Waters and Jiménez 2005), does not operate uniformly on all immigrants. Divergent outcomes have been observed between cohorts of immigrants (Picot and Heisz 2000) and between racial or visible minority groups (Ali and Grabb 1998; Caron Malenfant and Bélanger 2006; Corak 2008; Lian and Matthews 1998; Safi 2006). Yet, although the assimilation perspective has been challenged, our framework nevertheless underlines the importance of taking into account the duration of residence in the country when studying and projecting behaviours of newcomers. Thus, "duration of stay in the host country" and place of birth are introduced as important sources of potential change, for example in fertility behaviour or in the knowledge of the host country language. Moreover, according to Vertovec (2007), ethnicity or country of origin alone provide a misleading one-dimensional appreciation of 'super-diversity.' $\mathrm{He}$ also proposed the term to emphasize that "there is much to be gained by a multidimensional perspective on diversity both in terms of moving beyond the ethnic group as either the unit of analysis or sole object of study and by appreciating the coalescence of factors which condition people's lives" (Vertovec 2007: 1026). In our analysis, we therefore explore the complexity of super-diversity by using, in addition to duration of 
stay in the country of residence and place of birth, other dimensions of ethno-cultural diversity such as race, religion, or language proficiency when available.

In the second stage, knowledge arising from the analysis of ethno-cultural differentials is integrated into specific scenarios to inform the multiple assumptions supporting the microsimulation model. Importantly, these assumptions can be combined to create plausible population changes or policy-driven 'what-if' scenarios. In the context of the new immigration regime of high immigration and low fertility that describes the countries under study, we sought to evaluate the likely impacts of various future immigration scenarios. In other words, the level and composition of future cohorts of immigrants are treated as a policy-driven phenomenon. Characteristics of recent immigrants as observed in censuses or other sources can be used as a basis for a 'baseline' scenario, but these characteristics can also be modified through reweighting procedures to match any other desired distributions (changes in regions of origin or in education level of future immigrants, etc.).

Although central to the current demographic trends of high immigration and low fertility, immigration is not the only component of population change shaping the structure and composition of future populations. Most of the changes in the native population are assumed to be shaped in accordance with the Demographic Metabolism theory (Ryder 1965) which puts forward the importance of cohort succession to explain social changes. According to the theory, even if individuals' characteristics (education, language, etc.) tend to remain fairly stable over the life course, this process provides opportunity for social change due to the constant flow of new people entering the social process through birth and the continuous exit of older individuals through death (Lutz 2013).

For example, women with higher education levels not only tend to postpone childbearing but also show, in most countries, lower completed fertility compared to less educated women (Basten, Sobotka, and Zeman 2014). At the same time, increasing education also tends to postpone entry into the labour market, but increases work intensity (higher participation rate, lower unemployment) of both males and females over their lives, as it more than compensates for the late entry into the labour market due to a longer time spent studying (Mincer 1974). As younger cohorts entering the labour market or the childbearing ages are more educated than the older cohorts exiting it, the consequence is that, even if nothing else changes, we can expect that the total number of births would decline and that the total labour force population would increase over time. Thus, the future increase in average education level of the population, that is already built into the current age/education structure, will affect not only the composition of future population in terms of education level but also their future aggregated demographic (fertility, mortality) or economic (work intensity) behaviours. We want to measure these potential effects of demographic metabolism 
both from a cross-sectional perspective (total fertility rate, gross labour force participation rate, etc.) and longitudinal perspective (completed cohort fertility, cohort economic dependency ratio, etc.).

In the third stage, we use dynamic microsimulation to synthesize the outcomes of the two other phases in projection models. Microsimulation is a necessary technique to produce demographic and socioeconomic projections in the context of super-diversity, as it enables the modeling of complex behaviours and a large number of variables in a consistent and flexible way. The capacity of the microsimulation model to project many characteristics simultaneously also allows for the production of detailed tables of the projection results. Results can be displayed in the form of cross-sectional distributions of the population at different points in time up to the projection horizon but with many more details than would be possible with deterministic approaches to population projections.

\section{Microsimulation models for Canada, United States, and European Union}

Three microsimulation models were developed, one for Canada, one for the United States, and one for the $28 \mathrm{EU}$ member states of the European Union. All three share a common structure and general characteristics with respect to the analytical framework presented above. One necessary input to the microsimulation process is the base population, which must have micro-level information on the large number of individual characteristics related to 'super diversified' populations. At the minimum, detailed data is needed on birthplace and some other measure of diversity, either ethnicity (race), language, or religion. In addition, in order to add a socioeconomic dimension to the models, data on education levels and labour market activity is required.

The base population of all models comes from a public use microdata file of a recent survey or census. This allows for greater portability and also increases the transparency of the model and its potential usage, since its code and parameters, including the base population, can be shared without risk of breaching confidentiality rules, which are two important qualities to microsimulation models (Sutherland 2017). The base population of the Canadian model was extracted from the Public Use Microdata file of the 2011 National Household Survey (NHS). The survey numbers a little more than 880,000 cases and directly measures all the variables included in the microsimulation model (see Table 1 ). The base population of the American model was extracted from the 2015 American Community Survey (ACS). All variables were directly extracted from the ACS public use data file with the exception of religion, which was imputed from the 2014 PEW survey. In total, the base population numbers 
more than 3.1 million cases representative of the total American population. The base population of the European model was generated from the public use EU-Labour Force Survey microdata files. Language spoken at home and religion were imputed based on data extracted from the European Social Survey (all available waves since 2002). The two most recent waves of the EU-LFS Survey (2014 and 2015) were merged to increase the sample size, with the total base population numbering near 8.3 million cases.

All three models are time-based and event-based, dynamic, continuous time, open to international migration, stochastic (Monte Carlo) microsimulation projections and use the Modgen ${ }^{6}$ programming language. The models are time-based, meaning that all individuals are simulated for one stage in time (one year) before moving to the next stage in time. This allows for interactions between individuals and also for the use of contextual variables or feedback effects in the computation of the probability of the occurrence of a given event. The models are dynamic and in continuous time, meaning that characteristics of individuals are modified continuously in 'real time,' in contrast to discrete-time models, where characteristics are changed within predefined time units (typically one year). In discrete-time models, the model designer must decide a priori the order in which the events will occur. In a continuous time model, the precise duration of each event is calculated in three circumstances: 1) at the beginning of the simulation, 2) each time there is a change in a variable that features in the time function used to calculate a given event, and 3) after the occurrence of the event. Modgen automatically manages events' waiting queue changes. This allows for an easier treatment of competing risks. Age is a determinant of several events in the model, and we can use it to illustrate how competing risks are managed. Every time the (discrete) age of a simulated actor changes (at the birthday event) the risk of dying, of giving birth, of moving to another area, or of emigrating, of obtaining a new degree, or of being active or not, the labour market is recalculated and the waiting queue modified in consequence. Thus, in a sense, the birthday event competes with all these other events. ${ }^{7}$

All three models simultaneously project demographic (age, sex, place of residence, immigrant status), ethno-cultural (country of birth, language, and where possible other variables such as visible minority groups in Canada or race in the United States and religion in both Canada and Europe), and socioeconomic (education, labour force participation) characteristics. Table 1 details the categories of the different variables

\footnotetext{
${ }^{6}$ Modgen is a meta language of $\mathrm{C}++$ developed and maintained by Statistics Canada. Modgen and its documentation may be downloaded for free on Statistics Canada's website. Modgen models are coded and implemented in the Microsoft Visual Studio software suite. Once compiled, a Modgen model takes the form of a stand-alone executable file (.exe) that allows manipulation of the model through a graphical user interface. From this interface the user is able to modify simulation parameters and create customized scenarios.

${ }^{7}$ For more details and for Modgen model code of a simpler but similar microsimulation model, see Bélanger and Sabourin (2017).
} 
that are projected for each model. Accounting for immigration, all three models work with age at immigration and duration of residence in the country for immigrants. The models further allow for changes in individual characteristics over the life course as well as for inter-generational transfers of some characteristics of the mother to the child. Finally, the models are microsimulation projections. Individuals from the base populations are simulated one by one rather than projected as aggregated population groups as in the cohort-component or multi-state models. The occurrence of any events that shape the future population depends on a selection of individual characteristics that can vary from one type of event to another and between countries.

\section{Table 1: Description of the main data sources and variables included in the three microsimulation models}

\begin{tabular}{|c|c|c|c|}
\hline & Canada & European Union & United States \\
\hline \multicolumn{4}{|l|}{ Demographic variables } \\
\hline Age & $\begin{array}{l}0-100 \\
85+\text { as the open age group; } \\
\text { age is also a continuous } \\
\text { variable }\end{array}$ & $\begin{array}{l}0-100 \\
\text { Age is provided in } 5 \text { years age } \\
\text { groups in EU-LFS, assume a } \\
\text { uniform distribution of the } \\
\text { population in each single year of } \\
\text { age inside of a given age group }\end{array}$ & $\begin{array}{l}0-100 \\
85+\text { as the open age group; age } \\
\text { is also a continuous variable }\end{array}$ \\
\hline Sex & $\begin{array}{l}2 \text { categories } \\
\text { Female and Male }\end{array}$ & $\begin{array}{l}2 \text { categories } \\
\text { Female and Male }\end{array}$ & $\begin{array}{l}2 \text { categories } \\
\text { Female and Male }\end{array}$ \\
\hline Place of residence & $\begin{array}{l}24 \text { categories } \\
\text { Provinces and metropolitan } \\
\text { areas (CMAs) counting more } \\
\text { than } 500,000 \text { people and } 15 \% \\
\text { visible minorities; non-CMA } \\
\text { regions and smaller CMAs are } \\
\text { regrouped at the provincial level } \\
\text { into 'Rest of province' categories }\end{array}$ & $\begin{array}{l}28 \text { categories } \\
28 \text { European Union member } \\
\text { states }\end{array}$ & $\begin{array}{l}31 \text { categories } \\
\text { Major immigration } \mathrm{CMAs}^{8} \text {, rest } \\
\text { of major immigration states and } \\
\text { rest of census regions }\end{array}$ \\
\hline \multicolumn{4}{|l|}{ Ethno-cultural variables } \\
\hline Visible minority groups / Race & $\begin{array}{l}13 \text { categories } \\
\text { White, Aboriginal, South Asian, } \\
\text { Chinese, Black, Filipino, Latin } \\
\text { American, Arab, Southeast } \\
\text { Asian, West Asian, Korean, } \\
\text { Japanese, Other visible minority }\end{array}$ & & $\begin{array}{l}6 \text { categories } \\
\text { Non-Hispanic White, Black, } \\
\text { Asian, Hispanic, Other, Multi- } \\
\text { race }\end{array}$ \\
\hline Mother tongue & $\begin{array}{l}4 \text { categories } \\
\text { English and French as official } \\
\text { languages and two groups of } \\
\text { nonofficial language (Anglotrope } \\
\text { and Francotrope) }\end{array}$ & & \\
\hline
\end{tabular}

\footnotetext{
${ }^{8}$ The US major immigration CMAs are San Francisco, Southern California, rest of California, rest of Pacific, Houston, Dallas-Fort Worth, rest of West South Central, Miami, Orlando, Tampa, rest of Florida, Washington, DC, Atlanta, Raleigh-Durham, rest of South Atlantic, New York City, Philadelphia, rest of Middle Atlantic, Chicago, Detroit, rest of East-North-Central, Boston, rest of New England, Las Vegas, Phoenix, Denver, rest of Mountain, East-South-Central, St. Louis, Minneapolis, rest of West-North-Central.
} 
Bélanger et al.: A framework for the prospective analysis of ethno-cultural super-diversity

Table 1: (Continued)

\begin{tabular}{|c|c|c|c|}
\hline & Canada & European Union & United States \\
\hline \multicolumn{4}{|l|}{ Ethno-cultural variables } \\
\hline $\begin{array}{l}\text { Language spoken most } \\
\text { often at home }\end{array}$ & $\begin{array}{l}3 \text { categories } \\
\text { English, French, Other }\end{array}$ & $\begin{array}{l}3 \text { categories } \\
\text { Official language of the country } \\
\text { of residence, Other EU28 } \\
\text { language, Non EU28 language } \\
\text { (imputed from ESS) }\end{array}$ & $\begin{array}{l}3 \text { categories } \\
\text { English, Spanish, Other }\end{array}$ \\
\hline Knowledge of official language & $\begin{array}{l}4 \text { categories } \\
\text { English, French, English and } \\
\text { French, neither English nor } \\
\text { French }\end{array}$ & & \\
\hline English proficiency & & & $\begin{array}{l}3 \text { categories } \\
\text { English only, English proficient, } \\
\text { not English proficient }\end{array}$ \\
\hline Religion & $\begin{array}{l}8 \text { categories } \\
\text { No religion, Christian, Hindu, } \\
\text { Sikh, Muslim, Jewish, Buddhist, } \\
\text { Other religious affiliation }\end{array}$ & $\begin{array}{l}4 \text { categories } \\
\text { Christian, Muslim, No religion, } \\
\text { Other religious affiliation } \\
\text { (imputed from the European } \\
\text { Social Survey) }\end{array}$ & $\begin{array}{l}8 \text { categories } \\
\text { No religion, Christian, Hindu, } \\
\text { Sikh, Muslim, Jewish, Buddhist, } \\
\text { Other religious affiliation } \\
\text { (imputed from PEW } 2014 \\
\text { survey) }\end{array}$ \\
\hline Place of birth & $\begin{array}{l}27 \text { categories } \\
\text { Canada, United States, Central } \\
\text { America, Jamaica, Other } \\
\text { Caribbean and Bermuda, South } \\
\text { America, United Kingdom, } \\
\text { Germany, Other Northern and } \\
\text { Western Europe, Poland, Other } \\
\text { Eastern Europe, Italy, Portugal, } \\
\text { Other Southern Europe, Eastern } \\
\text { Africa, Northern Africa, Other } \\
\text { Africa, West Central Asia and } \\
\text { the Middle East, China, Hong- } \\
\text { Kong, Other Eastern Asia, } \\
\text { Philippines, Other Southeast } \\
\text { Asia, India, Pakistan, Other } \\
\text { Southern Asia, Oceania and } \\
\text { others }\end{array}$ & $\begin{array}{l}12 \text { categories } \\
\text { Own country, EU15, EU13, } \\
\text { Europe outside EU28, North } \\
\text { Africa, Other Africa, Near Middle } \\
\text { East, East Asia, Southeast Asia, } \\
\text { North America, Australia- } \\
\text { Oceania, Latin America } \\
\end{array}$ & $\begin{array}{l}11 \text { categories } \\
\text { United States, Mexico, Central } \\
\text { America and West Indies, South } \\
\text { America, Canada, Europe, East } \\
\text { Asia, Southeast Asia, Rest of } \\
\text { Asia, Africa, Other }\end{array}$ \\
\hline Immigration status & $\begin{array}{l}3 \text { categories } \\
\text { Non-Immigrant, Immigrant, Non- } \\
\text { Permanent Resident }\end{array}$ & $\begin{array}{l}3 \text { categories } \\
\text { - Non-immigrant, born in EU28, } \\
\text { born outside EU }\end{array}$ & $\begin{array}{l}2 \text { categories } \\
\text { US-Born, Immigrant }\end{array}$ \\
\hline Duration of residence & $\begin{array}{l}7 \text { categories } \\
\text { Native-born, 0-4 years, 5-9 } \\
\text { years, ..., 20-24 years, 25+ }\end{array}$ & $\begin{array}{l}7 \text { categories } \\
\text { Native-born, 0-4 years, 5-9 } \\
\text { years, ..., 20-24 years, 25+ }\end{array}$ & $\begin{array}{l}7 \text { categories } \\
\text { Native-born, 0-4 years, 5-9 } \\
\text { years, ..., 20-24 years, } 25+\end{array}$ \\
\hline Age at immigration & $0-100$ & $0-100$ & $0-100$ \\
\hline Generation status & $\begin{array}{l}5 \text { categories } \\
\mathrm{G} 1, \mathrm{G} 1.5, \mathrm{G} 2, \mathrm{G} 2.5, \mathrm{G} 3+\end{array}$ & $\begin{array}{l}3 \text { categories } \\
\mathrm{G} 1, \mathrm{G} 1.5, \mathrm{G} 2+\end{array}$ & $\begin{array}{l}3 \text { categories } \\
\mathrm{G} 1, \mathrm{G} 1.5, \mathrm{G} 2+\end{array}$ \\
\hline \multicolumn{4}{|l|}{ Socioeconomic variables } \\
\hline Education & $\begin{array}{l}4 \text { categories } \\
\text { Less than high school, High } \\
\text { school diploma, Post secondary } \\
\text { less than bachelor, University } \\
\text { diploma (bachelor or higher) }\end{array}$ & $\begin{array}{l}5 \text { categories } \\
\text { Less than high school, High } \\
\text { school diploma, Post secondary } \\
\text { less than bachelor, Bachelor } \\
\text { degree, Master or PhD degree }\end{array}$ & $\begin{array}{l}5 \text { categories } \\
\text { Less than high school, High } \\
\text { school diploma, Associates } \\
\text { degree, College, Professional } \\
\text { degree }\end{array}$ \\
\hline Education of the mother & & $\begin{array}{l}3 \text { categories } \\
\text { Less than high school, High } \\
\text { school diploma, Post secondary }\end{array}$ & $\begin{array}{l}3 \text { categories } \\
\text { Less than high school, High } \\
\text { school diploma, Post secondary }\end{array}$ \\
\hline
\end{tabular}


Table 1: (Continued)

\begin{tabular}{|c|c|c|c|}
\hline & Canada & European Union & United States \\
\hline \multicolumn{4}{|l|}{ Socioeconomic variables } \\
\hline Country of highest degree & $\begin{array}{l}2 \text { categories } \\
\text { Canada, Elsewhere }\end{array}$ & & \\
\hline Labour force participation & $\begin{array}{l}2 \text { categories } \\
\text { Active, Not in the labour force } \\
\text { (Inactive) }\end{array}$ & $\begin{array}{l}2 \text { categories } \\
\text { Active, Not in the labour force } \\
\text { (Inactive) }\end{array}$ & $\begin{array}{l}2 \text { categories } \\
\text { Active, Not in the labour force } \\
\text { (Inactive) }\end{array}$ \\
\hline Unemployment & & $\begin{array}{l}2 \text { categories } \\
\text { Employed, Unemployed }\end{array}$ & $\begin{array}{l}2 \text { categories } \\
\text { Employed, Unemployed }\end{array}$ \\
\hline \multicolumn{4}{|l|}{ Main data source } \\
\hline Survey & $\begin{array}{l}2011 \text { National Household } \\
\text { Survey Public-Use Microdata } \\
\text { File }\end{array}$ & $\begin{array}{l}\text { 2014-2015 EU-Labour Force } \\
\text { Survey and European Social } \\
\text { Survey (2001-2014), European } \\
2011 \text { Censuses }\end{array}$ & $\begin{array}{l}2015 \text { American Community } \\
\text { Survey }\end{array}$ \\
\hline Sample size & 882,287 & $8,297,031$ & $3,147,005$ \\
\hline Weights & $\begin{array}{l}\text { Average of } 60.2 \text {, range from } 0.1 \\
\text { to } 12026.0 \text {, adjusted to match } \\
\text { the } 2011 \text { population estimates } \\
\text { by age, sex, and province. }\end{array}$ & $\begin{array}{l}\text { Average of } 37.0 \text {, range from } \\
32.4 \text { to } 460.6 \text {, adjusted to match } \\
2011 \text { Census population counts } \\
\text { by age, sex, education, and } \\
\text { place of birth }\end{array}$ & $\begin{array}{l}\text { Average of } 102 \text {, range from } 1 \text { to } \\
3596 .\end{array}$ \\
\hline
\end{tabular}

We aimed at developing microsimulation models to project ethno-cultural diversity in selected developed countries to foresee the implications of high immigration on demographic trends and its socioeconomic impacts. Demographic and socioeconomic variables are derived from very similar concepts across all studied countries. All three models are by sex and by single year of age. All three models also account for internal migration between their sub-areas. The Canadian and the American models count 24 and 31 places of residence respectively representing the major immigration Census Metropolitan Areas of each country, residual sub-areas at the provincial level for Canada, and major immigration states or census regions at the state level for the United States. In the European model, sub-areas represent the $28 \mathrm{EU}$ member states. We use relatively broad education categories in order to obtain comparable groups despite significant differences in national education systems. The labour force status is defined in the same way in all the countries studied, and it is based on the International Labour Organization.

The nature of ethno-cultural variables, however, differ more between the three models due to different historical and social contexts. First, the notion of race or ethnic origin is absent from the European data used (and from most European surveys). In the United States, the race variable is built around racial groups (Black/White) and from Hispanic and Asian origins from which we created 6 categories, while in Canada the similar concept is defined into 12 categories of visible minority groups specified by the 1991 Law on employment and equity. 
Second, language variables are part of the Canadian Censuses since its beginning and are still omnipresent in Canadian surveys because of the dual French and English origins in Canada. Thus, the Canadian model projects the first language spoken by a person (mother tongue), language used at home, and knowledge of the official languages (English or French), but there is no question on language proficiency. The American survey asks only about the language spoken at home, but for those not using English it asks the level of proficiency in English, which for our purpose is probably a better concept than the Canadian one. Europe is, of course, a multilingual region where the official language (or languages in some cases) differs from one country to another. From the question on language spoken at home in the European Social Survey we derived a three-category variable that distinguishes speakers of the country's official language from those speaking another European language and those speaking a nonEuropean language.

Third, religion is directly asked in the Canadian decennial censuses, and the large sample size allowed for the creation of eight religious categories reflecting the most important groups of this highly multicultural country. The same categories were derived from the PEW survey and imputed to the American base population extracted from the ACS. In Europe, the smaller sample size of the European Social Survey used to impute religion to the base population and the high prevalence of Islam among non-Christian population forced us to create only four categories for the religion variable.

Finally, all three models have a sufficient number of regions of birth categories for foreign-born, but these categories differ between models to better reflect the immigration source countries of each. Age at immigration and duration of stay in the current country of residence for foreign-born is available in all three microsimulation models, but the place of birth of parents is only available in Canada, which allows for a more detailed generational status variable. Despite these limitations and inconsistencies across models, our models undoubtedly offer a new innovative tool to address issues related to super-diversity in high immigration developed countries.

For each event occurring in the projection model, Table 2 shows the individual characteristics taken into account to determine the probability of its occurrence and derive its waiting time. Each event can have its own set of determinants. Taking the example of fertility, in all three models, the risk of giving birth varies with age, region of residence, education, and immigrant status. However, microsimulation is a flexible methodology allowing the use of different equations and risk models for the same event according to an individual's region or country of residence. Thus, when available, other ethno-cultural determinants of fertility are accounted for, such as religion and visible minority groups in Canada or race in the United States.

There is not enough space here to further explain each of the modules of the microsimulation programs that allow the different characteristics of the simulated cases 
to evolve during the projection. However, each model is described in detail in a technical document available online to which the interested reader can refer (Bélanger et al. 2019, 2018). However, given the importance of international migration in our framework, it is important to describe how international immigration is treated in the models. Also, since several of the examples chosen to illustrate the usefulness of the projection model focus on activity, we also describe how the activity status is derived.

Emigration is modeled as an annual risk of out-migration in a manner similar to the migration between sub-areas of the projection model, except that rather than reassign a new place of residence to the actor being simulated, the occurrence of the emigration event terminates it and removes it from the projection. On the other hand, immigration is not treated as other events in the microsimulation models. This is because we are not projecting the rest of the world, and thus new immigrants coming during the projection are external to the model and must be created in the same way as the actors from the base population. ${ }^{9}$ The characteristics of recent immigrants (less than five years) from the base population are used as a basis to determine the characteristics of future immigrants in the simulation for baseline scenarios. In the simulation, whenever the record of a recent immigrant is read from the base population file, it is first simulated as a member of the base population and then re-simulated once in every year of the projection as a new immigrant. This method for generating immigrants implies that all immigrant cohorts have the same characteristics as recent immigrants from the base population. To allow for some variation, the individual weights are adjusted to match desired distributions. Through reweighting, it is thus possible to change the total volume of immigration during the simulation. It is also possible to change the immigrant distribution according to different characteristics such as age or education. Thus, the annual number of immigrants and their characteristics are predetermined within user-defined scenarios for each simulation.

${ }^{9}$ Their starting times, however, are spread all along the course of the simulation. 
Table 2: Determinants of the different events in the microsimulation models

\begin{tabular}{|c|c|c|c|c|c|c|c|c|c|c|c|c|c|}
\hline & $\stackrel{5}{8}$ & œ & 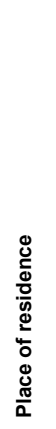 & 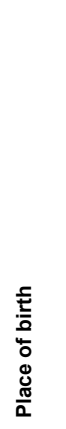 & 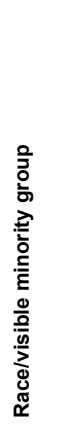 & 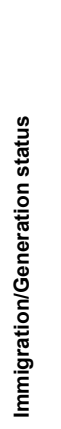 & 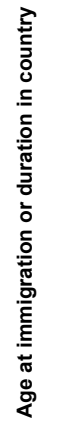 & 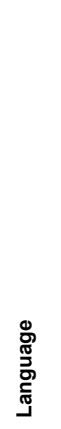 & 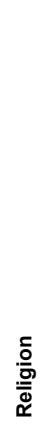 & 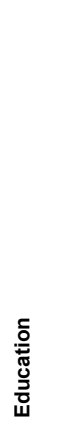 & 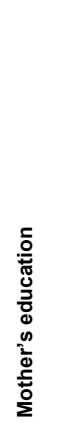 & 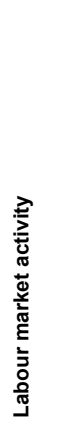 & 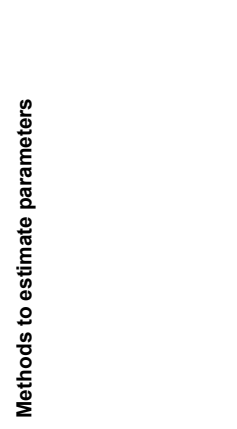 \\
\hline Fertility & $x$ & & $\mathrm{x}$ & $\mathrm{x}$ & $\mathrm{C}, \mathrm{U}$ & $\mathrm{x}$ & $\mathrm{x}$ & & C & $x$ & & & $\begin{array}{l}\text { Vital statistics, logistic } \\
\text { regression }\end{array}$ \\
\hline Mortality & $\mathrm{x}$ & $\mathrm{x}$ & $\mathrm{x}$ & c & & & c & & & c & & & $\begin{array}{l}\text { Population estimates, } \\
\text { Cox regression }\end{array}$ \\
\hline Internal migration & $\mathrm{x}$ & $\mathrm{x}$ & $\mathrm{x}$ & $\mathrm{C}, \mathrm{U}$ & $\mathrm{C}, \mathrm{U}$ & & $\mathrm{C}, \mathrm{U}$ & $\mathrm{C}, \mathrm{U}$ & c & $\mathrm{C}, \mathrm{U}$ & & $\mathrm{C}, \mathrm{U}$ & $\begin{array}{l}\text { Logistic regression, O/D } \\
\text { matrices }\end{array}$ \\
\hline Emigration & $x$ & $x$ & $x$ & c & & & & & & & & & $\begin{array}{l}\text { Population estimates, } \\
\text { relative risks }\end{array}$ \\
\hline $\begin{array}{l}\text { Official language } \\
\text { acquisition/Language used at home }\end{array}$ & $x$ & & $x$ & & & $\mathrm{x}$ & $x$ & $\mathrm{x}$ & & & & & $\begin{array}{l}\text { Survival curves, O/D } \\
\text { matrices }\end{array}$ \\
\hline Intergenerational language shift & & & $x$ & & & $x$ & & $\mathrm{x}$ & & & & & O/D matrices \\
\hline $\begin{array}{l}\text { Intergenerational transfers of } \\
\text { race/visible minority }\end{array}$ & & & & & $\mathrm{C}, \mathrm{U}$ & $\mathrm{C}, \mathrm{U}$ & & & & & & & O/D matrices \\
\hline Intergenerational transfers of religion & $x$ & $\mathrm{x}$ & $\mathrm{C}, \mathrm{U}$ & & & $\mathrm{C}, \mathrm{U}$ & & & $C, U$ & & & & O/D matrices \\
\hline Education attainment & $\mathrm{x}$ & $\mathrm{x}$ & $\mathrm{x}$ & $\mathrm{x}$ & $\mathrm{C}, \mathrm{U}$ & $x$ & & $\mathrm{x}$ & E & & $E, U$ & & $\begin{array}{l}\text { Multinomial/Ordered } \\
\text { logit }\end{array}$ \\
\hline Literacy & c & c & c & c & & c & & c & & c & & c & Linear regression \\
\hline Labour force participation & $\mathrm{x}$ & $\mathrm{x}$ & $\mathrm{x}$ & & $\mathrm{C}, \mathrm{U}$ & $\mathrm{x}$ & $\mathrm{x}$ & & & $\mathrm{x}$ & & & Logistic regression \\
\hline
\end{tabular}

Note: $\mathrm{X}=$ All models, $\mathrm{C}=$ Canada, $\mathrm{E}=\mathrm{EU} 28, \mathrm{U}=\mathrm{USA}$.

\section{Results}

The microsimulation models provide a lot of flexibility in terms of scenario building. Assumptions can be made on the future evolution of the different components of population change both in terms of the general intensity of the phenomenon or its composition. Assumptions about future immigration, for instance, can be made not only on the size of the future cohorts of immigrants, but also in terms of its composition by country of origin, education level, or any other characteristics that can be relevant. 
In this section, we provide five examples that demonstrate ways that the microsimulation models can be used. The first example is a simulation that projects ethno-cultural and socioeconomic changes for the baseline scenario only. That is, the scenario assumes the continuation of current trends and generally replicates the medium scenario of national statistical agencies in terms of projected population size and age structure. The second example is a simulation of the consequences of changing levels of immigration. It specifically focuses on labour force consequences of different levels of immigration by constructing stylised scenarios where the number of immigrants is doubled or set to zero. The third example is a simulation that assesses the impact of changing characteristics of immigrants. It simulates the impact of modifying the composition of migrant cohorts by assuming that immigrants to the EU28 or to the United States have the same distribution by education level as Canadian immigrants. In the fourth example, we illustrate the possibility of presenting results at a more detailed geographic scale. Finally, the fifth example illustrates the way the model can be used to provide estimates calculated over the lifetime of cohorts, thus taking a longitudinal perspective for estimates of labour force characteristics. These examples are presented to illustrate the possibilities of the model. A proper evaluation of any proposed policies on international migration would need full treatment in further research.

\subsection{Example 1: Ethno-cultural diversity}

Figure 2 shows the projected evolution of three indicators of diversity for Canada, the United States, and the EU28: the percentage of foreign-born population (in the EU28 case, it is the proportion of the population born outside the EU), the percentage of the population using a non-official language at home, and the percentage of nonChristians ${ }^{10}$. In terms of the percentage of foreign-born population, Canada is starting at a much higher level (21\%) compared to the United States (14\%) and the EU28 (8\%). Compared to the United States, Canada has an immigration rate twice as high and even higher compared to the EU28. Assuming that this situation would continue, Canada's foreign-born population would continue to grow and would likely reach $30 \%$ in 2061 . Europe's foreign-born population would grow at a faster pace than in the other two regions. At the end of the projection horizon, the European population can be composed of about 19\% foreign-born, which is higher than the projected proportion for the United States.

${ }^{10}$ The percentages of non-Christian are excluding the non-affiliated. 


\section{Figure 2: Proportion of the projected population with different ethno-cultural} characteristics, 2011-2056, Canada, USA, EU28
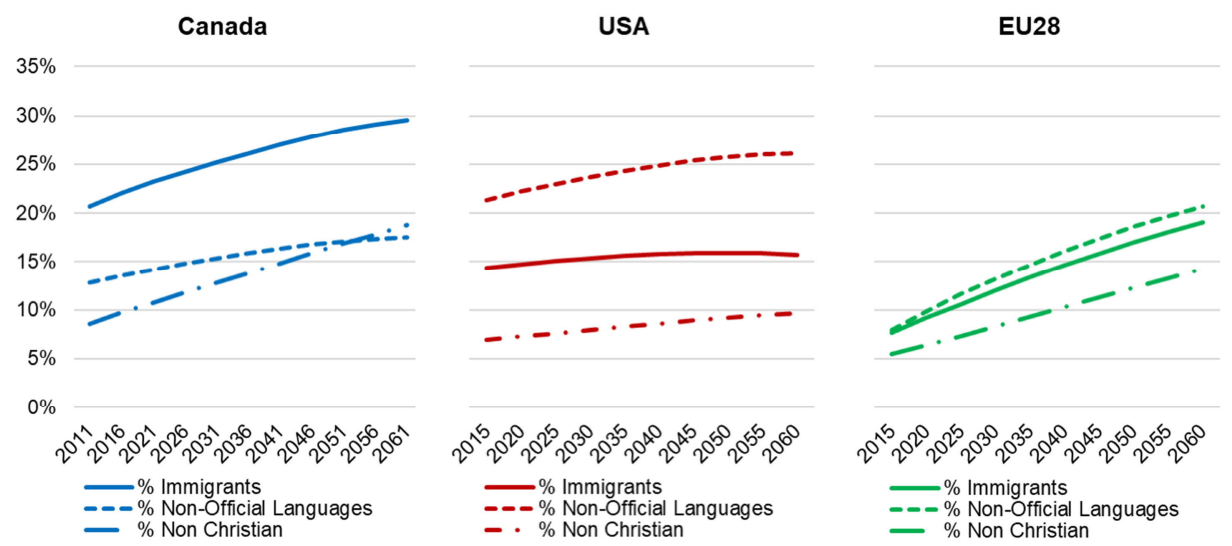

Looking at the second indicator, the proportion of the population using a nonofficial language at home, the picture is much different. Canadian immigration is much more diverse in its origins and languages spoken than what is observed in and projected for the other two regions. Also, there is a larger share of its immigrant population that already speaks the official languages (English and French) at arrival compared to the United States, where a large share of immigrants speaks Spanish. Perhaps because of this greater heterogeneity, the retention of foreign languages might be lower in Canada than elsewhere. As a consequence, even if Canada has the highest share of foreign-born and a fast increase in that share, the United States shows a much higher proportion of its population using a non-official (mostly Spanish) language at home.

Religion is another relevant ethno-cultural characteristic for the projection of diversity as religious diversity is often seen as a source of social fragmentation and declining social cohesion (Alesina et al. 2003; Goujon et al. 2007). Again, the progression of this indicator draws a different picture. At the start of the projection, the proportion of non-Christians is higher in Canada, and it is expected to grow fast during the projection period. In the United States and in EU28, the proportion of non-Christian population is projected to increase faster than the proportions of immigrants or the proportion of the population using a non-official language at home. This is because children of immigrants born in the country of destination are by definition native-born and because the inter-generational transfer of religion is lower than the intergenerational transfer of language. Although children born in an immigrant family where a non-official language is spoken will also use that language at home, they are more 
likely to experience a language shift when forming their own family than to undergo a change in faith.

\subsection{Example 2: Immigration and linguistic composition}

Figure 3 illustrates the impact of different levels of immigration on the linguistic composition of future labour force by assuming stylised scenarios where the number of immigrants is either doubled or set to zero (emigration rates remain the same as in the baseline scenario). Although they start at different levels, the pattern shown by the evolution of this variable is similar in Canada and in the United States. In the baseline scenario and the doubling migration scenario, the percentage of the population using a non-official language at home increases rapidly at first, but the rate of increase decreases with time. In the EU, the percentage of non-official language starts at a lower level at the beginning of the projection period, but increases faster than in Canada and the United States. In the no-migration scenario, the percentage of the population using a non-official language at home would go down in Canada and the United States, but would remain at about the same level in the EU. This is due to the fact that in the European model migrations between EU-28 countries are treated as internal migration and are thus continuing at the same pace as before in the zero-migration scenario.

\section{Figure 3: Percent of the population speaking a non-official language at home under three different assumptions of immigration, Canada, the USA and EU28, 2011-2061}
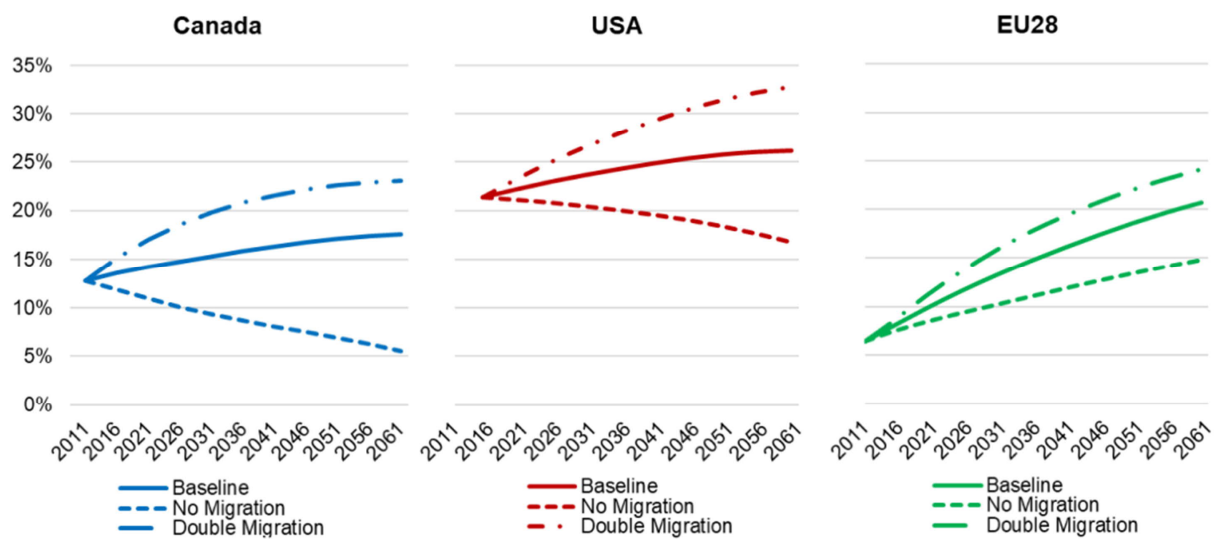


\subsection{Example 3: The educational attainments of immigrants}

Canada's immigration policy is often praised for its point-based selection system, which focuses on variables linked with human capital such as age, education, and knowledge of the official languages. Because of this point-based system, Canada has a higher proportion of graduated immigrants when compared to many other immigration countries. It is interesting to explore how modifying the immigrant selection process rather than modifying the size of future immigration cohorts could alter the future composition of working populations in terms of education attainment. The indicator is obtained by creating a scenario that attributes the Canadian immigrants' distribution by education level to projected immigrants in the other models.

Figure 4 illustrates such an investigation by looking at what could be the potential impact of modifying the composition of migrant cohorts on the size of the active population with post-secondary education in the EU28 and United States. To put an emphasis on the evolution of the working population with post-secondary education rather than on the different population size or educational levels observed in the two models, results are scaled to 100 in 2015.

The solid lines in the figure represent the projected increase of highly educated in the active population under the baseline scenario, and we can see that this number is likely to increase faster in the United States than in the EU 28. The dotted lines represent the possible evolution of that indicator if future immigrants would be selected using a Canadian-like point system (CanSce). For both regions, this scenario shows a faster increase in the number of highly educated, but the differences between the selection and the baseline scenarios are more important in the European model than in the American model. At the end of the projection, we observe a difference of 11 percentage points between the two American scenarios and a difference of 15 points in the European case. 
Figure 4: Growth of the active population with post-secondary education $(2015=100)$, the USA and EU28 2015-2060 baseline scenario (Ref.), and a scenario where immigrants are selected using a Canadian-like point system (CanSce)

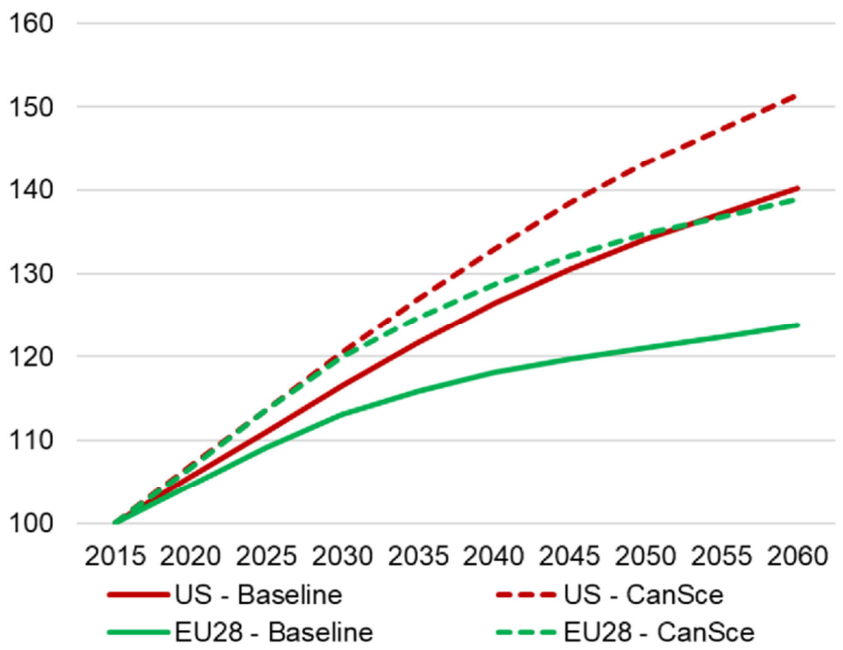

\subsection{Example 4: Regional variations}

The models have an important regional component that does not appear in the results presented so far. In the Canadian and American cases, regions are formed from geographic information on the metropolitan area and the state (in the United States) or province (in Canada). It is thus possible to analyse the future impact of immigration on high immigration regions such as New York, Los Angeles, and Miami in the United States or Montreal, Toronto, and Vancouver in Canada. The analysis can focus on the ethno-cultural changes in the population composition or on the impact of immigration on different labour markets in terms of active and inactive population. In the European case, the regions represent each of the national populations forming the EU28, and regional analyses would thus be limited to countries.

To illustrate the possibilities of presenting results at another geographic scale, Figure 5 shows the projected change in the population distribution by religious affiliation in six of the G7 countries (Japan is missing).

In all six countries, the share of Christians decreases but for different reasons. In the United States, most immigrants are Christians, and the 9 points decrease in the 
percentage of Christians over the projection period results almost all from an increase in Non Affiliated; the Muslims and 'Other' religions categories have their share increased by only 1 percentage point over the projection period. In the European countries, by contrast, the decrease in the proportion of Christians is much less attributable to disaffiliation and much more to the faster increase in the number of Muslims. Between 2011 and 2060, the baseline scenario projects an increase of the Muslims' share, varying between 8 percentage points for Italy and 11 percentage points for France. Since the baseline scenario assumes that the characteristics of future immigrants will be the same as the most recent immigrants, the share of the 'Other' religions category barely changes over the projection period in all European countries. Reflecting the more diverse origins of Canadian immigrants, the figure also shows that in the Canadian case, the decrease in the share of Christians is associated with both a faster increase in the population of Muslim (plus 7 percent points) and of other religions (plus 3 percent points).

Figure 5: Observed (2011/2015) and projected (2060/2061) total population by religious affiliation, Canada, USA, EU28, baseline scenario

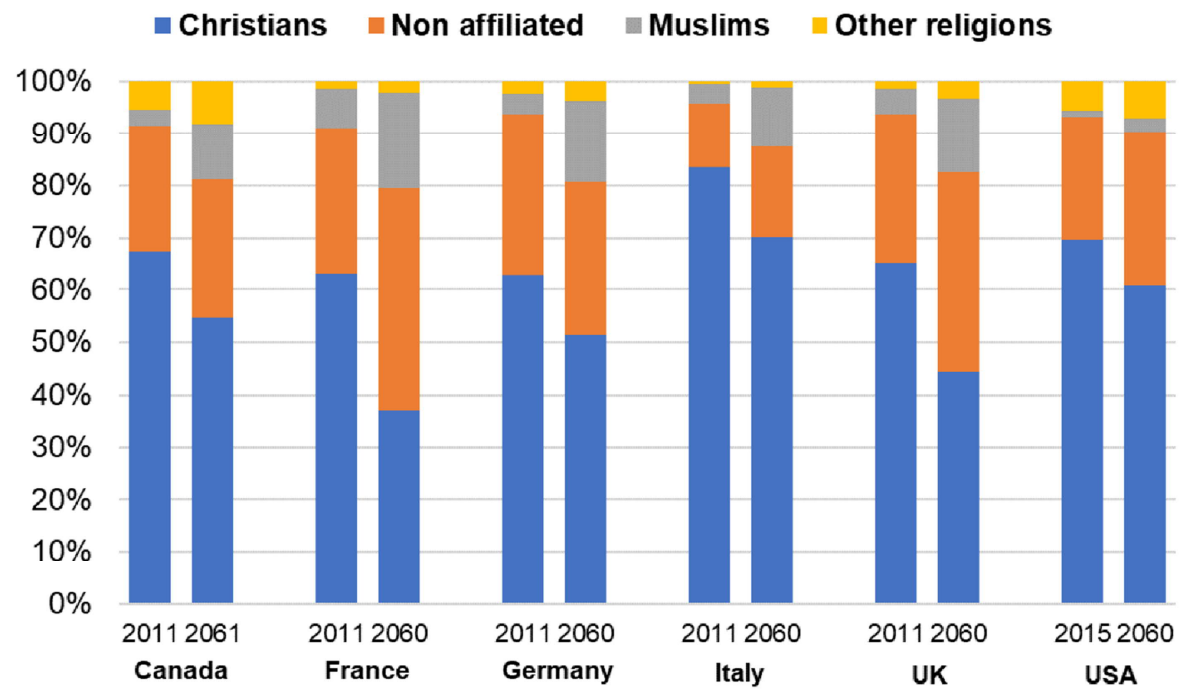




\subsection{Example 5: A cohort perspective to economic dependency ratio}

The examples provided just now are essentially cross-sectional analyses in that they provide estimates of the size or composition of the population or population subgroups at various points in time. However, our microsimulation models also permit a longitudinal analysis that follows individuals over time. As an example, to better determine the impact of immigration on pension plan sustainability (at least in a pay-asyou-go type of pension plan), it is preferable to take a longitudinal perspective and count the number of years lived as active and inactive over the life course for foreignborn and native-born cohorts.

We carried out this analysis and present the results in Figure 6, which compares the cohort economic dependency ratios of foreign- and native-born by education level. The cohort economic dependency ratio (CEDR) is defined as the ratio between the number of years lived inactive divided by the number of years lived active over the life course. It takes into account the increase in life expectancy as well as, in our microsimulation model, the increase in older workers labour force participation and the increase in educational attainment. CEDR also considers differentials in labour force participation by immigrant status and education level and differentials in educational attainment between population groups. In the context of current labour market changes, it is important to take these characteristics of the population and their plausible evolution in the different regions into consideration to better estimate the potential effects of immigration. Education is generally completed by age 25 and, for that reason, we compute the CEDR for the population aged 25 and over.

We note on Figure 6 that for all educational groups combined, the CEDR is higher for immigrants compared to natives, meaning that in general immigrants contribute fewer years of activity for each year lived inactive. The differences between natives and immigrants are larger in the EU-28 and smaller in the United States. In the EU28, an immigrant can expect to live 1.22 years inactive for each year lived active compared to 0.82 for a European-born. In the United States the corresponding ratios are much closer with 0.89 and 0.74. Canada has the lowest CEDR for both its native (0.65) and immigrant (0.79) population.

Looking next at the differences in CEDR by educational level, we note that the ratios tend to be lower for higher educational levels. This holds for natives and immigrants alike. Higher participation rates over the working life and higher age at retirement add up to fewer years lived as inactive for each year lived as active among the more educated population. Additionally, immigrants have higher ratios than natives for all educational levels except for the less than high school level in the United States, although the differences between immigrants and natives tend to decrease as education level increases. 
Figure 6: Cohort economic dependency ratios (CEDR) of immigrants and natives by education levels, Canada, USA, and EU28
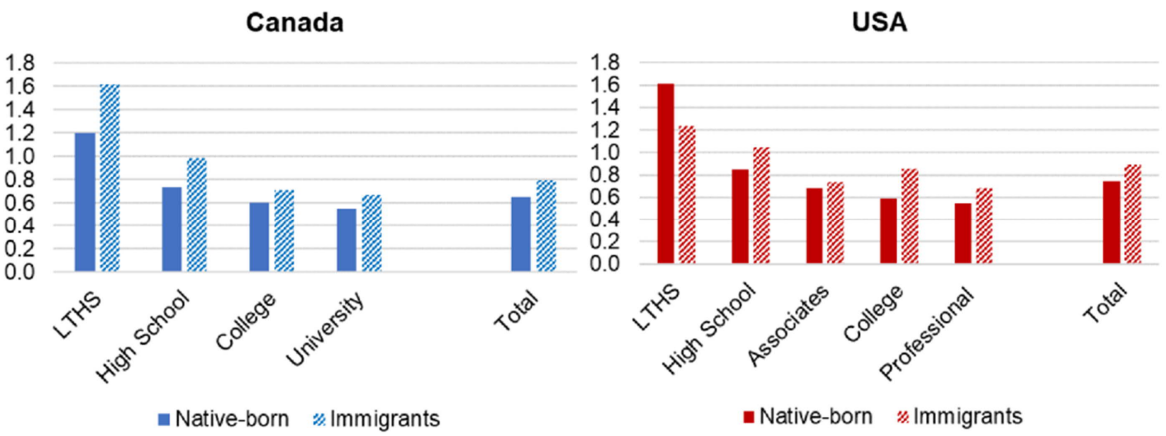

EU28

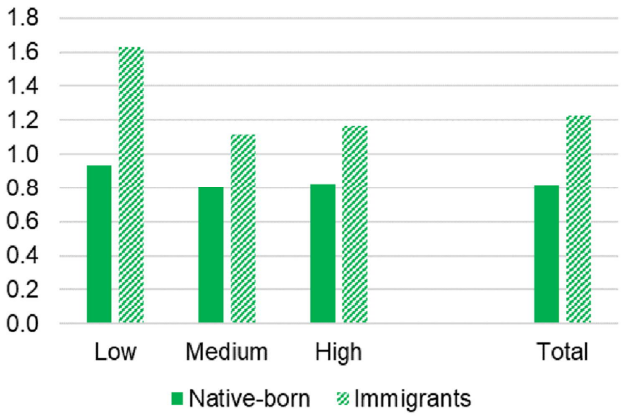

\section{Discussion and conclusion}

The main objective of this paper was to present the analytical framework supporting our efforts in analysing prospective super-diversity in high immigration countries. We believe that this is important because these societies are getting more diverse at a rapid pace. The increase in immigration and the resulting increase in diversity are often praised for their economic and social benefits and for other advantages, such as impact on research and innovation. Ethnic, linguistic, and religious diversities have become, and will likely continue to be, a critical matter with political and social implications in several countries. Alesina et al. (2003) showed that ethnic and linguistic fragmentation can contribute to slower economic growth, and more homogeneous countries also tend to be better governed. More recently, Patsiurko, Campbell, and Hall (2012) applied a similar analysis to 30 OECD countries for two periods (1985 and 2000). They showed 
that the negative relationship between ethnic fragmentation and economic growth is also present in the context of developed economies. Increasing diversity from mass migration can also have a negative impact on aspects of social capital like shared norms and trust (Levy 2017; Putnam 2007) and have influenced critical political outcomes such as the Brexit (Coleman 2016; Gietel-Basten 2016), the rise of populism movements such as the one leading to the election of Donald Trump in the United States, or the recent entrance of deputies from an extreme right party (Alternative für Deutschland) in the Germans' Bundestag for the first time since World War II. Projecting the changes in population composition in terms of diversity has therefore an interest per se.

Another important aspect of our model and analysis is the focus on the projection of educational attainment and labour force activity. Although international immigration has, at best, only a small effect on a country's population aging, the concentration of immigrant cohorts in the working age groups can certainly help in addressing slower and possibly negative labour force population growth, at least for high immigration regions. By increasing the number of workers, increasing immigration can decrease the economic dependency ratio of a population, but in a context of below replacement fertility, adopting such a solution leads to a continuously increasing need for immigration (United Nations 2000). At best, this is a short-term view. In addition, simply increasing the working age population through immigration might not help the economy if the number of inactives increases faster than the number of actives because of low labour force participation rates among migrants (Bélanger and Bastien 2013).

A second objective of this paper was to present the general structure of the microsimulation models and to show how much more informative results from this type of projection models can be in comparison to more traditional cohort-component or multi-state models. We illustrated this point by presenting a selection of results that demonstrate the capacity of the model to address a variety of research questions. In doing so, the paper only superficially touches upon the issues related to population changes coming with super-diversity. The models provide many opportunities to conduct future in-depth studies, many of which are currently in preparation. There are certain limitations that must be reminded, notably for the international comparisons results and analyses. In the European model, the regions represent each of the national populations forming the EU28, while in the Canadian and American models, regions are formed from geographic information on cities, states, or provinces. As a result, in the European model, immigrants are both EU-nationals, which are moving from one EU country to another, and foreign-born people moving into Europe. Policy-wise, the European results, hence, cannot be directly compared to the American and Canadian projections, since in the latter, internal migration streams never create international migrants. 


\section{Acknowledgements}

The research leading to these results has received funding from the Canadian Social Sciences and Humanities Research Council (SSHRC) under the Insight program (grant $\mathrm{N}^{\circ} 425-2015-1152$ ). The European microsimulation model was developed as part of the Centre of Expertise on Population and Migration (CEPAM), a joint research project of the International Institute for Applied Systems Analysis (IIASA), and the Joint Research Centre (JRC) of the European Commission. 


\section{References}

Abbasi-Shavazi, M.J. and McDonald, P. (2000). Fertility and multiculturalism: Immigrant fertility in Australia, 1977-1991. International Migration Review 34(1): 215-242. doi:10.1177/019791830003400109.

Alesina, A., Devleeschauwer, A., Easterly, W., Kurlat, S., and Wacziarg, R. (2003). Fractionalization. Journal of Economic Growth 8(2): 155-194. doi:10.3386/ w9411.

Ali, J. and Grabb, E. (1998). Ethnic origin, class origin and educational attainment in Canada: Further evidence on the mosaic thesis. Journal of Canadian Studies 33(1): 3-21. doi:10.3138/jcs.33.1.3.

Anderson, G.F. and Hussey, P.S. (2000). Population aging: A comparison among industrialized countries. Health Affairs 19(3): 191-203. doi:10.1377/hlthaff. 19.3.191.

Andersson, G. (2004). Childbearing after migration: Fertility patterns of foreign-born women in Sweden. International Migration Review 38(2): 747-774. doi:10.1111/j.1747-7379.2004.tb00216.x.

Auerbach, A.J. and Lee, R. (2011). Welfare and generational equity in sustainable unfunded pension systems. Journal of Public Economics 95(1-2): 16-27. doi:10.1016/j.jpubeco.2010.09.008.

Australian Department of Immigration and Citizenship (2012). The outlook for net overseas migration. Belconnen: Department of Home Affairs. http://www. immi.gov.au/media/publications/statistics/immigration-update/nom-jun12.pdf.

Aydemir, A. and Skuterud, M. (2005). Explaining the deteriorating entry earnings of Canada's immigrant cohorts, 1966-2000. The Canadian Journal of Economics 38(2): 641-671. doi:10.1111/j.0008-4085.2005.00297.x.

Barrett, A. (1998). The effect of immigrant admission criteria on immigrant labourmarket characteristics. Population Research and Policy Review 17(5): 439-456. doi:10.1023/A:1006077209783.

Basten, S., Sobotka, T., and Zeman, K. (2014). Future fertility in low fertility countries. In: Lutz, W., Butz, W.P., and KC, S. (eds.). World population and human capital in the twenty-first century. Oxford: Oxford University Press: 39-149. doi:10.1093/acprof:oso/9780198703167.003.0003. 
Beach, C.M., Green, A.G., and Reitz, J.G. (2003). Canadian immigration policy for the $21^{\text {st }}$ century. Montreal: McGill-Queen's University Press.

Bélanger, A. and Bastien, N. (2013). Immigration, education, ethnocultural diversity and the future composition of the Canadian labour force. Population and Development Review 39(3): 509-525. doi:10.1111/j.1728-4457.2013.00614.x.

Bélanger, A. and Gilbert, S. (2003). The fertility of immigrant women and their Canadian-born daughters. In: Bélanger, A. (ed.). Report on the demographic situation in Canada 2002. Ottawa: Statistics Canada: 135-161.

Bélanger, A. and Sabourin, P. (2017). Microsimulation and population dynamics: An introduction to Modgen 12. Cham: Springer. doi:10.1007/978-3-319-44663-9.

Bélanger, A., Lachapelle, R., and Sabourin, P. (2011). Persistance et orientation linguistiques de divers groupes d'allophones au Québec. Montreal: Office québécois de la langue française. https://www.oqlf.gouv.qc.ca/ressources/ sociolinguistique/etudes2011/20110909_Persistance_orientation.pdf.

Bélanger, A., Sabourin, P., Vézina, S., Marois, G., D’Ovidio, K., Lafontaine, O., Van Hook, J., and Morse, A. (2019). The United States Microsimulation Model (LSD-USA): Methodological document. Montreal: Laboratoire de Simulations Démographiques de l'INRS. http://sd.inrs.ca/wp-content/uploads/2019/05/ LSD_USA.pdf.

Bélanger, A., Sabourin, P., Vézina, S., Marois, G., D’Ovidio, K., Pelletier, D., and Lafontaine, O. (2018). The Canadian microsimulation model (LSD-C): Content, modules, and some preliminary results. Montreal: Institut National de la Recherche Scientifique (Working Paper 2018-01). http://espace.inrs.ca/6830/.

Bloom, D.E., Grenier, G., and Gunderson, M. (1994). The changing labor market position of Canadian immigrants. Cambridge: National Bureau of Economic Research (NBER Working Paper Series 4672). doi:10.3386/w4672.

Bonikowska, A., Green, D.A., and Riddell, W.C. (2008). Literacy and the labour market: Cognitive skills and immigrant earnings. Ottawa: Statistics Canada. https://www150.statcan.gc.ca/n1/en/pub/89-552-m/89-552-m2008020-eng.pdf.

Borjas, G.J. (1987). Immigrants, minorities, and labor market competition. ILR Review 40(3): 382-392. doi:10.1177/001979398704000305.

Borjas, G.J. (1989). Immigrant and emigrant earnings: A longitudinal study. Economic Inquiry 27(1): 21-37. doi:10.1111/j.1465-7295.1989.tb01161.x. 
Borjas, G.J. (1994). The economics of immigration. Journal of Economic Literature 32: 1667-1717. doi:10.3386/w4955.

Boudarbat, B. and Boulet, M. (2007). Détérioration des salaires des nouveaux immigrants au Québec par rapport à l'Ontario et à la Colombie-Britannique. Choix IRPP 13(7): 1-34.

Boudarbat, B. and Boulet, M. (2010). Un diplôme postsecondaire canadien: Un tremplin vers des emplois de qualité pour les immigrants? Montreal: Institut de Recherche en Politiques Publiques (Étude IRPP 8). http://irpp.org/wp-content/ uploads/assets/Uploads/IRPP-study-no2.pdf.

Bourbeau, R. (2002). L'effet de la sélection d'immigrants en bonne santé sur la mortalité canadienne aux grands âges. Cahiers québécois de démographie 31(2): 249-274. doi:10.7202/000667ar.

Boyd, M. and Cao, X. (2009). Immigrant language proficiency, earnings, and language policies. Canadian Studies in Population 36(1-2): 63-86. doi:10.25336/ P6NP62.

Büchel, F. and Frick, J.R. (2005). Immigrants' economic performance across Europe: Does immigration policy matter? Population Research and Policy Review 24(2): 175-212. doi:10.1007/s11113-004-1370-4.

Caldwell, J.C. and Schindlmayr, T. (2003). Explanations of the fertility crisis in modern societies: A search for commonalities. Population Studies 57(3): 241-263. doi:10.1080/0032472032000137790.

Caron Malenfant, É. and Bélanger, A. (2006). The fertility of visible minority women in Canada. In: Bélanger, A. (ed.). Report on the demographic situation in Canada 2003 and 2004. Ottawa: Statistics Canada: 79-95.

Chen, J., Wilkins, R., and Ng, E. (1996). Life expectancy of Canada's immigrants from 1986 to 1991. Health Reports 8(3): 29-38.

Citizenship and Immigration Canada (2012). Facts and figures 2012: Immigration overview: Permanent and temporary residents. Ottawa: Citizenship and Immigration Canada. http://publications.gc.ca/collections/collection_2013/cic/ Ci1-8-2012-eng.pdf.

Coale, A.J. and Watkins, S.C. (1986). The decline of fertility in Europe. Princeton: Princeton University Press.

Cohen, R. and Van Hear, N. (2008). Global diasporas: An introduction. London: Routledge. doi:10.4324/9780203928943. 
Colby, S.L. and Ortman, J.M. (2014). Projections of the size and composition of the US population: 2014 to 2060: Population estimates and projections. Washington, D.C.: US Census Bureau (Current Population Reports 25-1143).

Coleman, D. (2006). Immigration and ethnic change in low-fertility countries: A third demographic transition. Population and Development Review 32(3): 401-446. doi:10.1111/j.1728-4457.2006.00131.x.

Coleman, D. (2009). The demographic effects of international migration in Europe. Oxford Review of Economic Policy 24(3): 452-476. doi:10.1093/oxrep/grn027.

Coleman, D. (2016). A demographic rationale for Brexit. Population and Development Review 42(4): 681-692. doi:10.1111/padr.12014.

Corak, M. (2008). Immigration in the long run: The education and earnings mobility of second-generation Canadians. IRPP Choices 14(13): 1-30.

Duncan, B. and Trejo, S.J. (2011). Tracking intergenerational progress for immigrant groups: The problem of ethnic attrition. American Economic Review 101(3): 603-608. doi:10.1257/aer.101.3.603.

Ferrer, A. and Riddell, W.C. (2004). Education, credentials, and immigrant earnings. Canadian Journal of Economics 41(1): 186-216. doi:10.1111/j.1365-2966.2008. 00460.x.

Frejka, T. and Ross, J. (2001). Paths to subreplacement fertility: The empirical evidence. Population and Development Review 27(Supplement: Global Fertility Transition): 213-254.

Frey, W.H. (2014). Diversity explosion: How new racial demographics are remaking America. Washington, D.C.: Brookings Institution Press.

Gavrilov, L.A. and Heuveline, P. (2003). Aging of population. In: Demeny, P. and McNicoll, G. (eds.). The encyclopedia of population. New York: Macmillan Reference USA: $32-37$.

Geschwender, J.A. and Guppy, N. (1995). Ethnicity, educational attainment, and earned income among Canadian-born men and women. Canadian Ethnic Studies 27(1): $67-84$.

Gietel-Basten, S. (2016). Why Brexit? The toxic mix of immigration and austerity. Population and Development Review 42(4): 673-680. doi:10.1111/padr.12007. 
Goujon, A., Skirbekk, V., Fliegenschnee, K., and Strzelecki, P. (2007). New times, old beliefs: Investigating the future of religions in Austria and Switzerland. Vienna Yearbook of Population Research 2007: 237-270. doi:10.1553/ populationyearbook2007s237.

Hummer, R.A., Benjamins, M.R., and Rogers, R.G. (2004). Racial and ethnic disparities in health and mortality among the US elderly population. In: Anderson, N.B., Bulatao, R.A., and Cohen, B. (eds.). Critical perspectives on racial and ethnic differences in health in late life. Washington, D.C.: The National Academies Press: 53-94.

Jennissen, R., Van Der Gaag, N., and Van Wissen, L.E.O. (2006). Searching for similar international migration trends across countries in Europe. Genus 62(2): 37-64.

Kahn, L.M. (2004). Immigration, skills and the labor market: International evidence. Journal of Population Economics 17(3): 501-534. doi:10.1007/s00148-0030151-4.

Lanzieri, G. (2011). Fewer, older and multicultural? Projections of the EU populations by foreign/national background. Luxembourg: Eurostat.

Lesthaeghe, R. and Willems, P. (1999). Is low fertility a temporary phenomenon in the European Union? Population and Development Review 25(2): 211-228. doi:10.1111/j.1728-4457.1999.00211.x.

Levy, M. (2017). The effect of immigration from Mexico on social capital in the United States. International Migration Review 51(3): 757-788. doi:10.1111/imre. 12231.

Lian, J.Z. and Matthews, D.R. (1998). Does the vertical mosaic still exist? Ethnicity and income in Canada, 1991. Canadian Review of Sociology 35(4): 461-481. doi:10.1111/j.1755-618X.1998.tb00732.x.

Lichter, D.T. (2013). Integration or fragmentation? Racial diversity and the American future. Demography 50(2): 359-391. doi:10.1007/s13524-013-0197-1.

Lutz, W. (2013). Demographic metabolism: A predictive theory of socioeconomic change. Population and Development Review 38(S1): 283-301. doi:10.1111/ j.1728-4457.2013.00564.x.

Lutz, W. and Bélanger, A. (2017). Demographic change and the drivers of future migration into Europe: Approach, methodology and work plan of the JRC/IIASA Centre of Expertise on Population and Migration. Laxenburg: International Institute for Applied Systems Analysis. 
Lutz, W., Butz, W.P., and KC, S. (2014). World population and human capital in the twenty-first century. Oxford: Oxford University Press. doi:10.1093/acprof:oso/ 9780198703167.001.0001.

Mahroum, S. (2001). Europe and the immigration of highly skilled labour. International Migration 39(5): 27-43. doi:10.1111/1468-2435.00170.

Marois, G., Sabourin, P., and Bélanger, A. (2017). A microsimulation approach for modelling the future human capital of EU28 member countries. Laxenburg: International Institute for Applied Systems Analysis (WP 17-017).

Martel, L., Caron-Malenfant, É., Vézina, S., and Bélanger, A. (2007). Projections de la population active au Canada, 2006-2031. Canadian Economic Observer 20(6).

Martin, P. and Ruhs, M. (2011). Labor shortages and US immigration reform: Promises and perils of an independent commission. International Migration Review 45(1): 174-187. doi:10.1111/j.1747-7379.2010.00843.x.

Massey, D.S., Arango, J., Hugo, G., Kouaouci, A., Pellegrino, A., and Taylor, J.E. (1993). Theories of international migration: A review and appraisal. Population and Development Review 19(3): 431-466. doi:10.2307/2938462.

McDonald, P. (2002). Sustaining fertility through public policy: The range of options. Population 57(3): 417-446. doi:10.3917/pope.203.0417.

Meurs, D., Pailhé, A., and Simon, P. (2006). Persistance des inégalités entre générations liées à l'immigration: L'accès à l'emploi des immigrés et de leurs descendants en France. Population 61(5-6): 763-801. doi:10.3917/popu. 605.0763 .

Mincer, J.A. (1974). Schooling, experience, and earnings. New York: National Bureau of Economic Research.

Model, S. and Lin, L. (2002). The cost of not being Christian: Hindus, Sikhs and Muslims in Britain and Canada. International Migration Review 36(4): 10611092. doi:10.1111/j.1747-7379.2002.tb00118.x.

Münz, R. (2007). Europe: Population change and its consequences: An overview. Berlin: Institut für Bevölkerung und Entwicklung. https://www.berlin-institut. org/fileadmin/user_upload/Presseschau/pdf_Muenz_Europe.pdf.

Ng, E. and Nault, F. (1997). Fertility among recent immigrant women to Canada, 1991: An examination of the disruption hypothesis. International Migration 35(4): 559-580. doi:10.1111/1468-2435.00027. 
OECD (2000). Reforms for an ageing society. Paris: OECD. doi:10.1787/ 9789264188198-en.

OECD (2010). Migration and employment. In: OECD (ed.). OECD factbook 2010: Economic, environmental and social statistics. Paris: OECD: 26-27.

Park, J. and Myers, D. (2010). Intergenerational mobility in the post-1965 immigration era: Estimates by an immigrant generation cohort method. Demography 47(2): 369-392. doi:10.1353/dem.0.0105.

Parsons, G. (1994). The growth of religious diversity: Britain from 1945. London: Routledge.

Patsiurko, N., Campbell, J.L., and Hall, J.A. (2012). Measuring cultural diversity: ethnic, linguistic and religious fractionalization in the OECD. Ethnic and Racial Studies 35(2): 195-217. doi:10.1080/01419870.2011.579136.

Peach, C. (2005). The United Kingdom: A major transformation of the religious landscape. In: Knippenberg, H. (ed.). The changing religious landscape of Europe. Amsterdam: Het Spinhuis: 44-58.

Pew Research Center (2015). The future of world religions: Population growth projections, 2010-2050. Washington, D.C.: Pew Research Center. https://assets. pewresearch.org/wp-content/uploads/sites/11/2015/03/PF_15.04.02_Projections FullReport.pdf.

Picot, G. (2008). Immigrant economic and social outcomes in Canada: Research and data development at Statistics Canada. Ottawa: Statistics Canada. https://www150.statcan.gc.ca/n1/en/pub/11f0019m/11f0019m2008319-eng.pdf? st=NPdNjqN3.

Picot, G. and Heisz, A. (2000). The performance of the 1990s Canadian labour market. Canadian Public Policy 26: S7-S25. doi:10.2307/3552501.

Population Reference Bureau (2012). 2012 world population data sheet. Washington, D.C.: Population Reference Bureau. https://www.prb.org/wp-content/uploads/ 2012/07/2012-population-data-sheet_eng.pdf.

Portes, A. and Zhou, M. (1993). The new second generation: Segmented assimilation and its variants. The Annals of the American Academy of Political and Social Science 530(1): 74-96. doi:10.1177/0002716293530001006.

Preston, S., Heuveline, P., and Guillot, M. (2000). Demography: Measuring and modeling population processes. Hoboken: Wiley. 
Putnam, R.D. (2007). E pluribus unum: Diversity and community in the twenty-first century the 2006 Johan Skytte Prize Lecture. Scandinavian Political Studies 30(2): 137-174. doi:10.1111/j.1467-9477.2007.00176.x.

Rampton, B., Harris, R., and Leung, C. (1997). Multilingualism in England. Annual Review of Applied Linguistics 17: 224-241. doi:10.1017/S0267190500003366.

Rees, P., Wohland, P., Norman, P., and Boden, P. (2011). A local analysis of ethnic group population trends and projections for the UK. Journal of Population Research 28(2-3): 149-183. doi:10.1007/s12546-011-9047-4.

Rees, P., Wohland, P., Norman, P., and Boden, P. (2012). Ethnic population projections for the UK, 2001-2051. Journal of Population Research 29(1): 45-89. doi:10.1007/s12546-011-9076-z.

Rees, P.H., Wohland, P.N., and Norman, P.D. (2009). The estimation of mortality for ethnic groups at local scale within the United Kingdom. Social Science and Medicine 69(11): 1592-1607. doi:10.1016/j.socscimed.2009.08.015.

Ruhs, M. (2008). Economic research and labour immigration policy. Oxford Review of Economic Policy 24(3): 403-426. doi:10.1093/oxrep/grn034.

Ruhs, M. and Anderson, B. (2010). Who needs migrant workers? Labour shortages, immigration, and public policy. Oxford: Oxford University Press. doi:10.1093/ acprof:oso/9780199580590.001.0001.

Rumbaut, R.G., Massey, D.S., and Bean, F.D. (2006). Linguistic life expectancies: Immigrant language retention in Southern California. Population and Development Review 32(3): 447-460. doi:10.1111/j.1728-4457.2006.00132.x.

Ryder, N. (1965). The cohort as a concept in the study of social change. American Sociological Review 30(6): 843-861. doi:10.2307/2090964.

Safi, M. (2006). Le processus d'intégration des immigrés en France: Inégalités et segmentation. Revue française de sociologie 47(1): 3-48. doi:10.3917/rfs. 471.0003 .

Schultz, T.P. (1998). Immigrant quality and assimilation: A review of the US literature. Journal of Population Economics 11(2): 239-252. doi:10.1007/s001480050067.

Singh, G.K. and Miller, B.A. (2004). Health, life expectancy, and mortality patterns among immigrant populations in the United States. Canadian Journal of Public Health 95(3): I14-21. 
Statistics Canada (2003). Religions in Canada. Ottawa: Statistics Canada. http:// publications.gc.ca/Collection/Statcan/96F0030X/96F0030XIE2001015.pdf.

Statistics Canada (2007). The evolving linguistic portrait, 2006 census. Ottawa: Statistics Canada. http://publications.gc.ca/collections/collection_2007/statcan/ 97-555-X/97-555-XIE2006001.pdf.

Statistics Canada (2013). Immigration and ethnocultural diversity in Canada. Ottawa: Statistics Canada. https://www12.statcan.gc.ca/nhs-enm/2011/as-sa/99-010-x/ 99-010-x2011001-eng.pdf.

Sutherland, H. (2017). Quality profiling microsimulation models: The case of EUROMOD. Paper presented at the $6^{\text {th }}$ World Congress of the International Microsimulation Association, Torino, Italy, June 21, 2017.

Termote, M., Payeur, F., and Thibault, N. (2011). Perspectives démolinguistiques du Québec et de la région de Montréal (2006-2056). Montreal: Office québécois de la langue française. https://www.oqlf.gouv.qc.ca/ressources/sociolinguistique/ etudes2011/20110909_perspectives_demolinguistiques.pdf.

Trovato, F. (1981). Canadian ethnic fertility. Sociological Focus 14(1): 57-74. doi:10.1080/00380237.1981.10570382.

Trovato, F. (1985). Mortality differences among Canada's indigenous and foreign-born populations, 1951-1971. Canadian Studies in Population 12(1): 49-80. doi:10.25336/P68G6K.

Trovato, F. (1993). Mortality differences by nativity during 1985-87. Canadian Studies in Population 20(2): 207-223. doi:10.25336/P6BS35.

United Nations (2000). Replacement migration: Is it a solution to declining and ageing populations? New York: United Nations.

United Nations Population Division (2016). International migration report, 2015: Highlights. New York: United Nations.

United Nations Population Division (2017). World population prospects: The 2017 revision. New York: United Nations. doi:10.18356/b19523c6-en.

van Imhoff, E. and Post, W. (1998). Microsimulation methods for population projection. Population: An English Selection 10(1): 97-136.

Vertovec, S. (2007). Super-diversity and its implications. Ethnic and Racial Studies 30(6): 1024-1054. doi:10.1080/01419870701599465. 
Bélanger et al.: A framework for the prospective analysis of ethno-cultural super-diversity

Waters, M.C. and Jiménez, T.R. (2005). Assessing immigrant assimilation: New empirical and theoretical challenges. Annual Review of Sociology 31: 105-125. doi:10.1146/annurev.soc.29.010202.100026.

Winter, J. and Teitelbaum, M. (2013). The global spread of fertility decline: Population, fear, and uncertainty. New Haven: Yale University Press. doi:10.12987/yale/9780300139068.001.0001.

Young, C.M. (1987). Migration and mortality: The experience of birthplace groups in Australia. International Migration Review 21(3): 531-554. doi:10.1177/ 019791838702100305.

Zaiceva, A. and Zimmermann, K.F. (2008). Scale, diversity, and determinants of labour migration in Europe. Oxford Review of Economic Policy 24(3): 427-451. doi:10.1093/oxrep/grn028.

Zimmermann, K.F., Bonin, H., Fahr, R., and Hinte, H. (2007). Immigration policy and the labor market: The German experience and lessons for Europe. Berlin: Springer. 